\title{
Challenges to Quality Control in Bored Cast-In-Situ Piling in Growing Urban Environment
}

\author{
D. V. Karandikar ${ }^{1}$
}

Received: 28 April 2017/ Accepted: 22 September 2017/Published online: 6 October 2017

(C) Indian Geotechnical Society 2017

\begin{abstract}
Extensive bored cast-in-situ piling work is being carried out in growing metropolitan and other large cities for foundations of multi-storeyed office and residential buildings, flyovers and for retaining deep excavations for basements. The roads are small, traffic is heavy, there are restrictions on timings for movement of construction machinery and with all these limitations, the owners/clients require speedy construction of piled foundations to come 'above ground' for superstructure construction. Geotechnical consultants and piling contractors face tremendous challenges in urban environment in ensuring quality in piling work. The challenges relate to all aspects of piling work such as pile-bore retention during boring, pile tip zone cleaning, deciding socket lengths in deep weathered rocks, meeting the pile termination criteria, concreting without interruptions etc. In case of shoring piles for basement excavations, installation of anchors adds to a further challenge since they would penetrate in adjoining plot. Micropiles are also being extensively used without regard to their inherent limitations in installation and load carrying capacity. These aspects are discussed in the presented paper.
\end{abstract}

Keywords Bored piles · Quality control · Urban environment $\cdot$ Rotary auger rigs

D. V. Karandikar

dilipvk2002@yahoo.com; dilipvk@gmail.com

1 D.V. Karandikar \& Associates Consulting Engineers, Vile Parle (East), Mumbai 400057, India

\section{Introduction}

Rapid urbanization of cities with increasing population has necessitated construction of high rise residential and office buildings. The building foot-prints are small which result in imposing high loads columns which in turn are required to be supported on pile foundations. Bored cast-in-situ piling becomes the most suitable piling system. In urban environment the roads are small, traffic is heavy, there are restrictions on timings for movement of construction machinery and with all these limitations, speedy progress is required. Geotechnical consultants and piling contractors face tremendous challenges in ensuring quality in piling work. The challenges relate to all aspects of piling work such as equipment selection for pile boring, pilebore retention, pile tip zone cleaning, forming of stipulated socket length meeting the pile termination criteria and concreting without interruptions. Challenges also exist when piles are used for shoring to protect the excavations for deep basements. Use of micropiles for supporting building loads or for excavation shoring bring in further challenges. All these issues are discussed in this paper based on author's experience.

\section{Pile Boring Methods}

Pile boring is normally carried out by one of the three methods, viz.,

(a) Chisel-Bailor method using temporary casing

(b) Direct Mud Circulation (DMC) method using bentonite slurry and

(c) deploying Rotary Hydraulic Auger Drilling Rigs. 
In congested urban environment all these methods encounter problems which affect pile installation and its quality.

\section{Chisel-Bailor Method}

In small and narrow access urban plots, this method can be used. It is slow and uses temporary mild steel (M.S.) casing for pile bore stability during boring. It is this aspect of use of a temporary casing that throws in a major challenge. The depth of a temporary casing is limited to about 6-7 m only. This is due to the difficulties in casing extraction owing to large frictional resistance on its outer surface caused by surrounding soil. Permanent M.S. casing going deeper is avoided due to its high cost. Thus with short casing, the pile bore at lower depth remains vulnerable to caving resulting in necking, bulging and even loss of concrete in pile shaft (Figs. 1, 2). Consequently piles have to be either discarded or derated. Their long term durability also remains suspect due to reduction in concrete cover. Problem increases in high sulphate bearing and high chloride soils which are aggressive to concrete and reinforcement.

\section{DMC Method}

This method is faster than Chisel-Bailor but requires making of bentonite slurry tanks and arranging inflow/

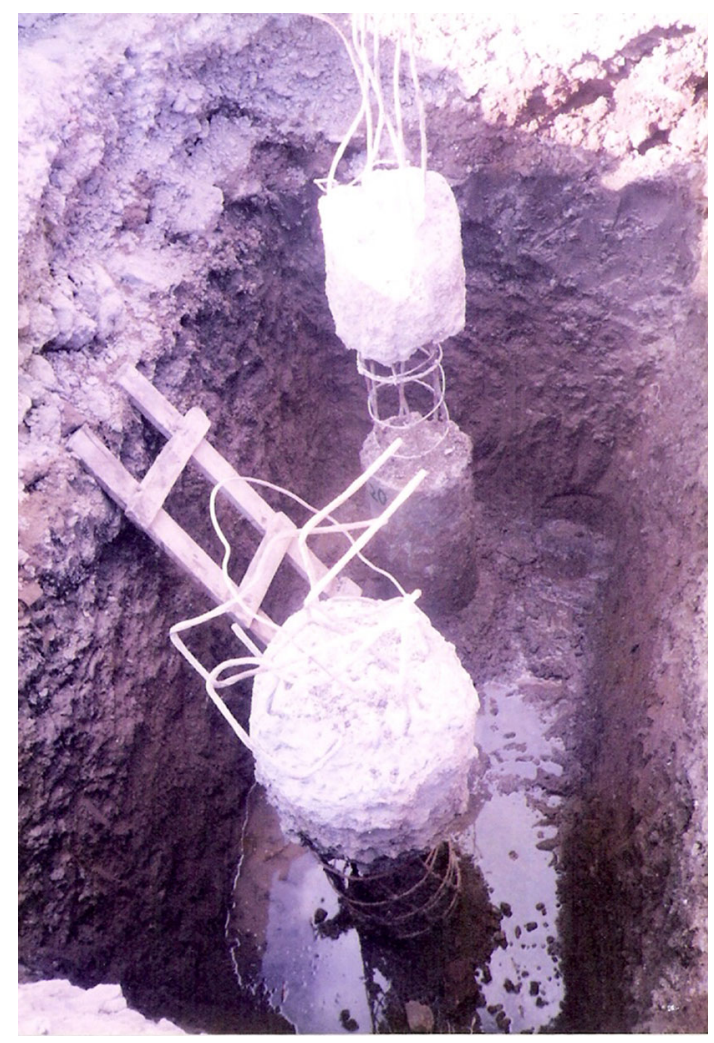

Fig. 2 Piles with severe shaft integrity problem with loss of concrete in pile shafts
Fig. 1 Necking and bulging defects in bored cast-in-situ piles

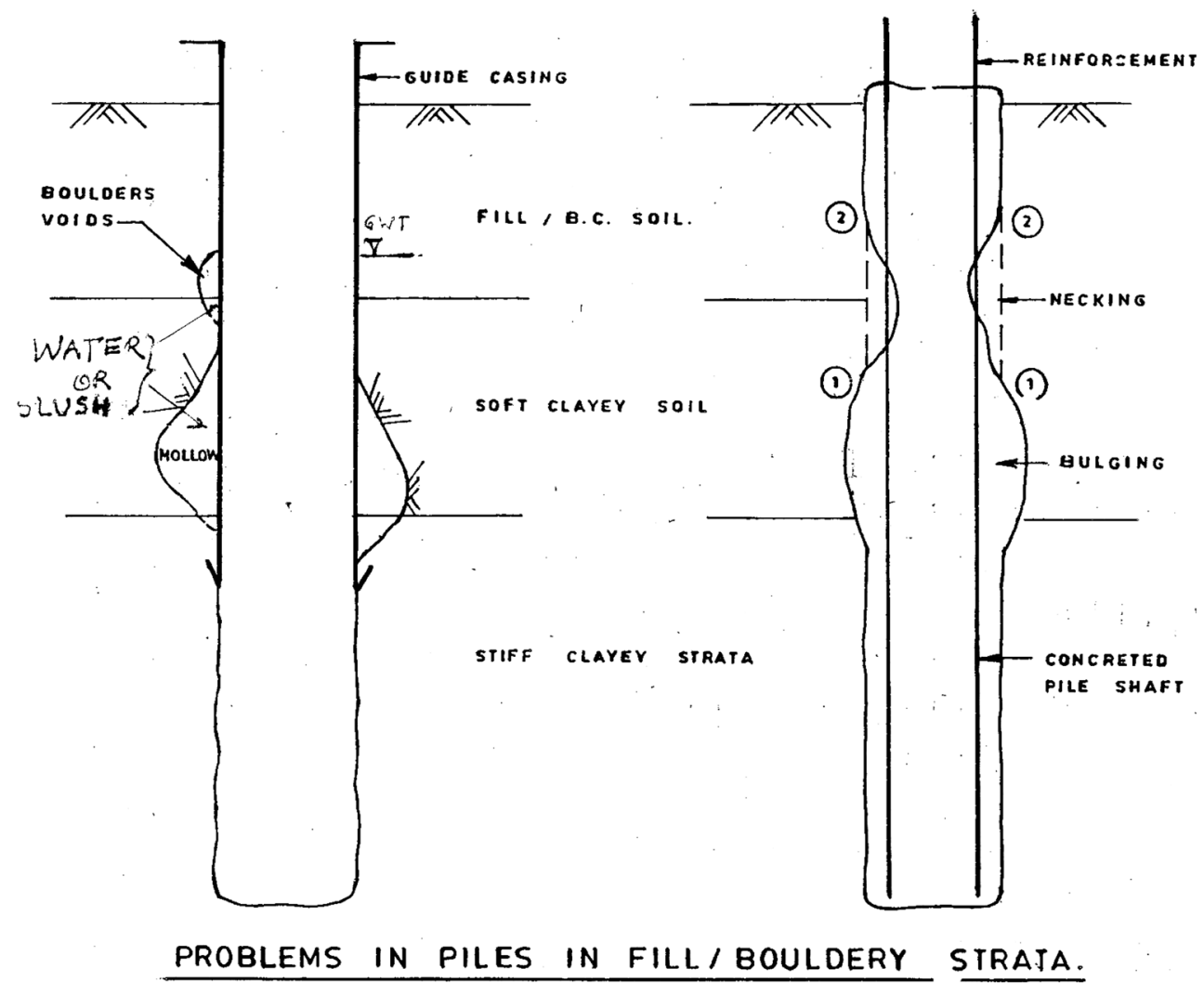


outflow slurry pipes and channels. In urban area, space restriction often does not permit such an arrangement. Besides, the site gets very slushy and muck disposal is delayed due to difficulties in its handling. The environmental norm does not allow slurry disposal in municipal drains. DMC method therefore is the least preferred one in urban areas.

Use of bio-degradable polymer fluid is an option to bentonite slurry but at present it is not popular with piling contractors due to higher cost and lack of adequate training in its use.

\section{Hydraulic Rotary Auger Rigs}

Due to their fast operation, giving rapid progress in piling work, use of hydraulic rotary auger rigs is preferred and its adoption is becoming more and more common. But there are many issues of quality control, which get overlooked affecting piling quality. In this paper, these issues have been more specifically elaborated.

\section{Quality Control Issues with Rotary Auger Piling}

These issues relate to (a) selection of rotary rig, (b) local geological factors, (c) pile bore stability, (d) pile shaft integrity, (e) pile tip zone cleaning, and (f) concreting without interruptions. These are discussed below and case studies are presented to highlight the same.

\section{Selection of Rotary Rig}

This should normally be done based on the type of rock, its strength, extent of fracturing and grade of weathering. The required rock socket length also, has to be kept in mind. Site access will also dictate the selection of rig.

Due to extensive piling work that is presently going on, rotary rigs are in high demand and the piling contractor tends to use the available rig, either his own or a hired one, overlooking the need for selection of an appropriate rig for the rock type and its insitu rock mass condition.

If the rock is hard, lower capacity rigs are not efficient and the pile termination criterion is not met with and the socket length gets compromised/reduced. In highly fractured rock, the rock auger teeth/bullets can not properly grip the joints to rip the rock and pile boring becomes difficult and time consuming. Teeth/bullets often break, wear out fast, their replacements do not come in time and piling gets delayed. Similar is the case when site is filled with boulders. The boulders tend to fall in pile bore and boring tends to deviate from verticality.

Piling contractors need to seek guidance from the rig manufacturers on selection of piling rig, cutting tools etc. Typical guidance from one such manufacturer is given below in Fig. 3 wherein based on compressive strength of rock, the type of auger to be used has been recommended.

\section{Compressive strength $\mathrm{MPa}$}

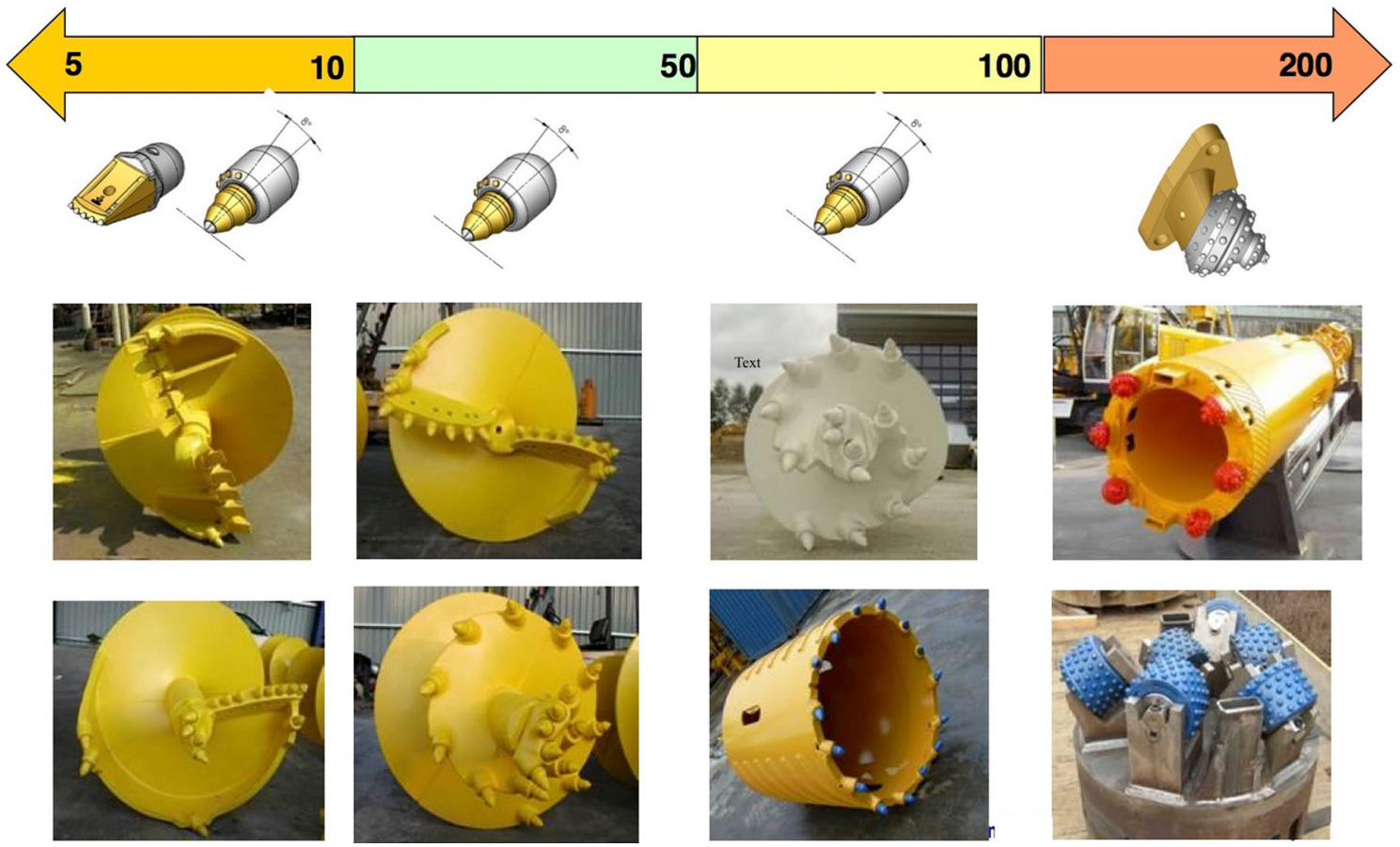

Fig. 3 Selection of tools based on rock strength 


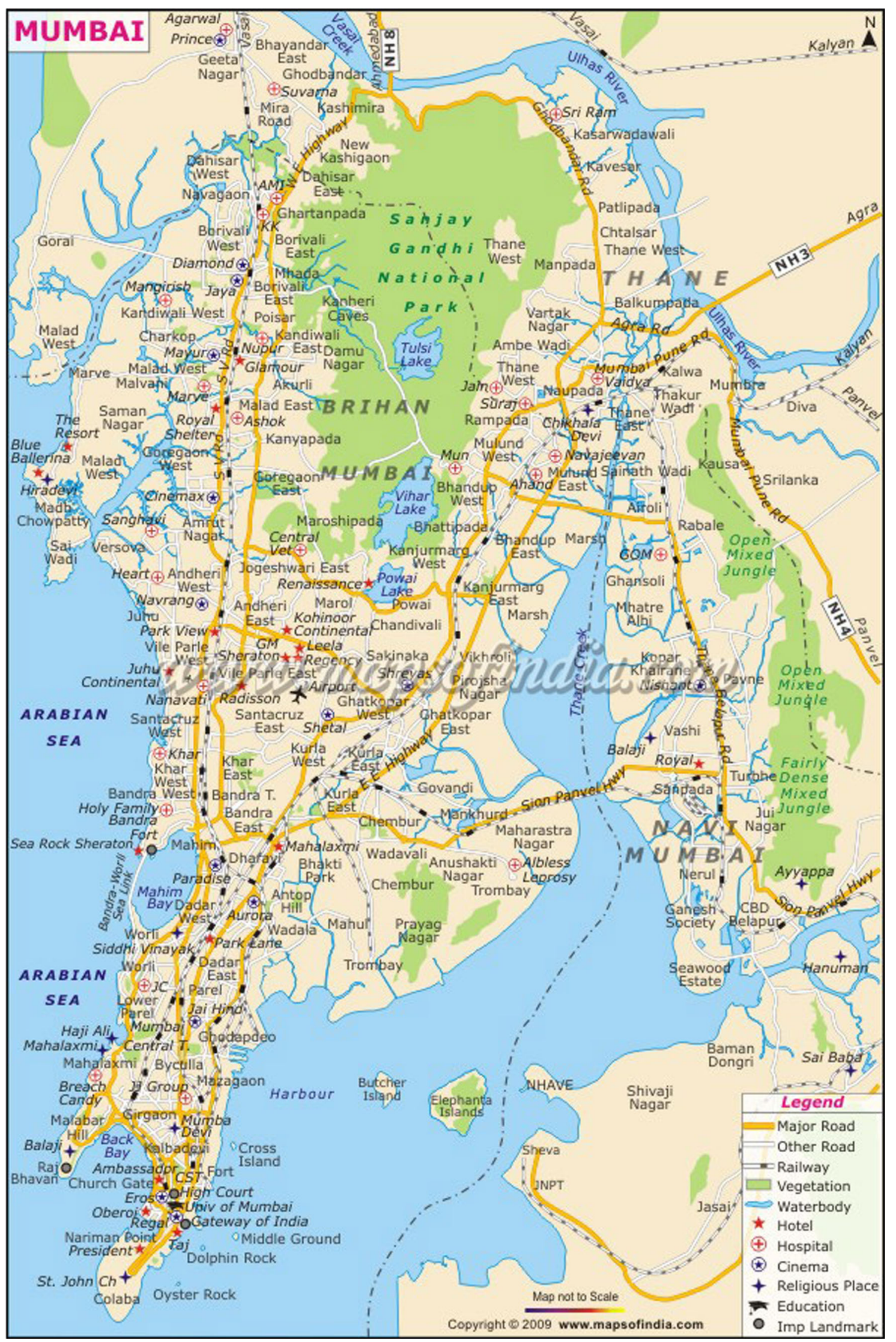

Fig. 4 Present day Mumbai 
Fig. 5 Original topography of Mumbai with seven islands

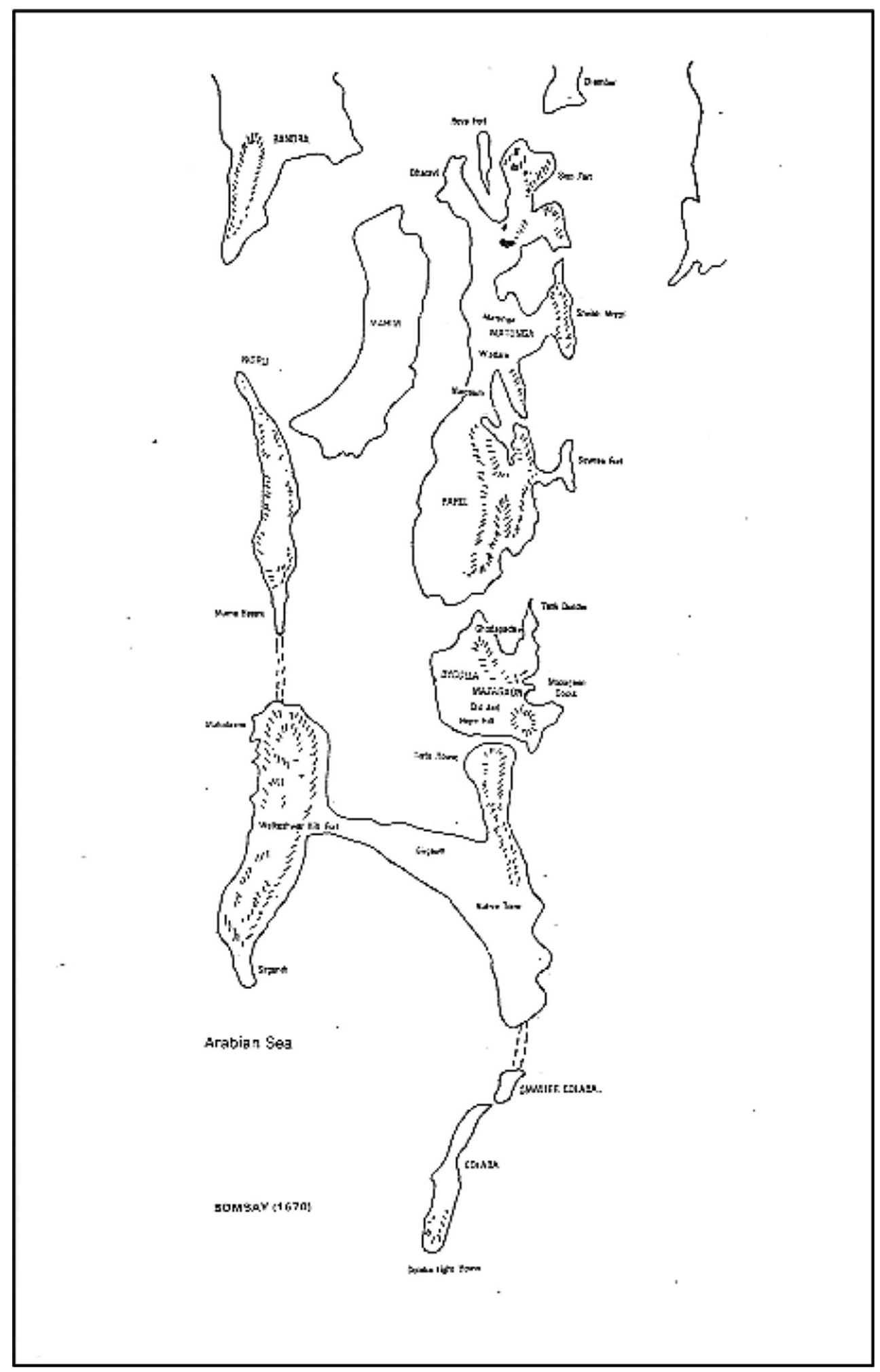

\section{Local Geological Factors}

Very often local geological factors are overlooked in piling work. For example, the present day Mumbai (Fig. 4) is known to have been formed by reclamation of seven islands (Fig. 5). Far away from the present sea shore we find reverse sequence of deposits, i.e. sand overlying soft marine clay. This can happen if site in the past was near the island shore. Implication of this deposit sequence is often overlooked. 


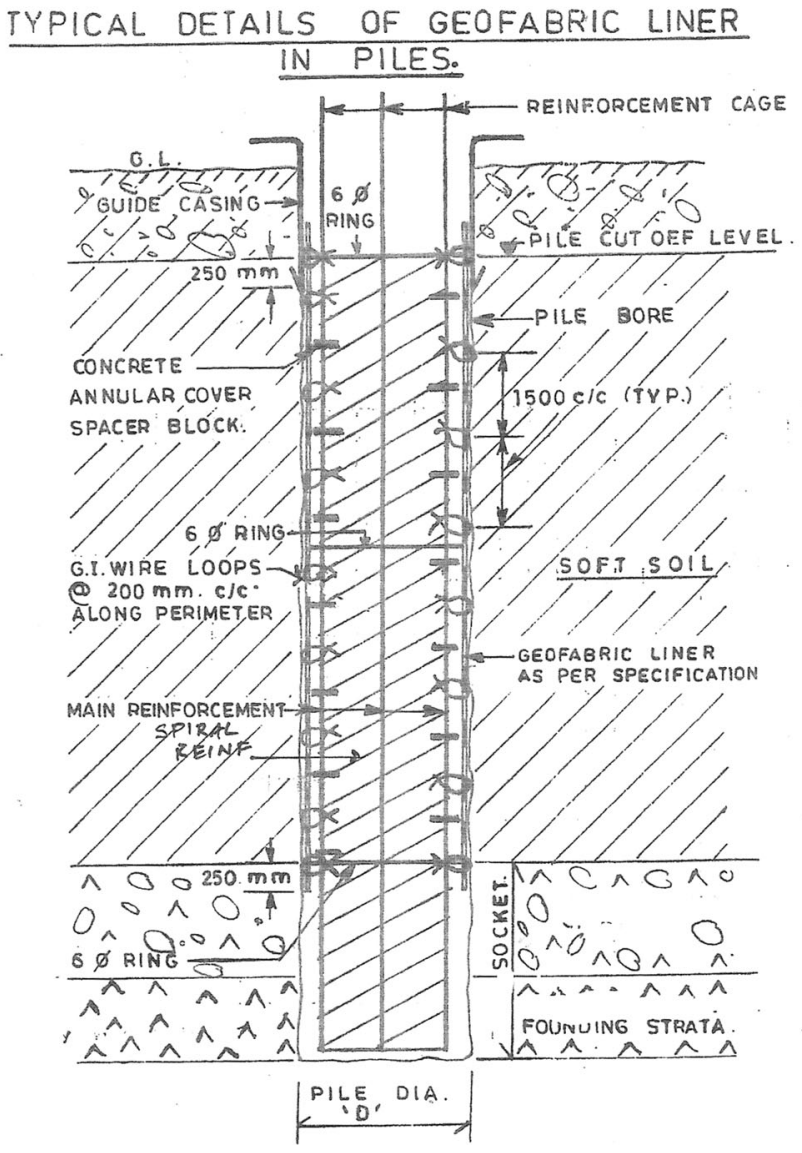

Fig. 6 Typical arrangement of Geofabric pile liner

Fast rotary augering relies on temporary cohesion in upper sandy strata and formation of slurry due to lower marine clay for stabilizing the pile bore. This makes the pile bore prone for slumping. As given in the case studies presented, the piles at such sites had severe shaft integrity problem which got further enhanced due to 'soft toe' condition. Many piles had to be discarded or drastically derated and due to smaller foundation footprint, positioning of new piles became extremely difficult. New piles had to have permanent M.S. liners and pile tip zone cleaning was done by airlift method using polymer fluid.

The Mumbai geology also adds to surprises due to presence of volcanic ash, weak Tuff, Breccia, Intertrappean Shale in Basalt or Trachyte rock mass. Selection of pile boring rig needs careful study of borehole and other geotechnical investigation data. Hydrothermal 'spheroidal' weathering of these rocks yields hard boulders in the matrix of silty clay which fall into pile bore and create difficulties for maintaining verticality of pile bore. Presence of Basaltic dykes altogether removes the need for piling even in a small plot, where some columns would still need piles.

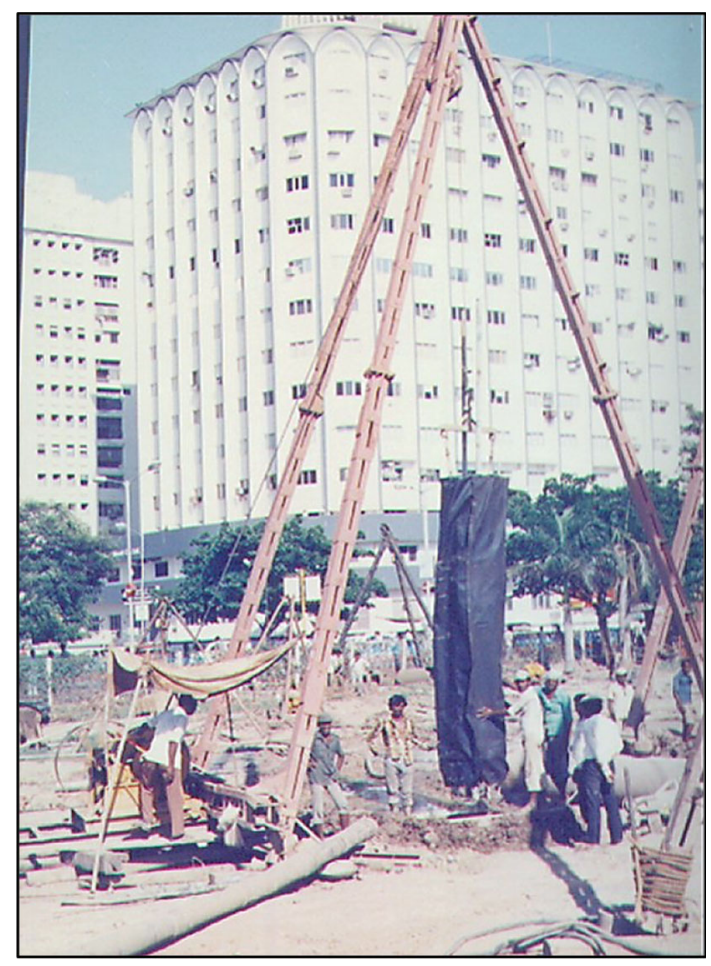

Fig. 7 Geofabric pile liner with bituminous slip coating

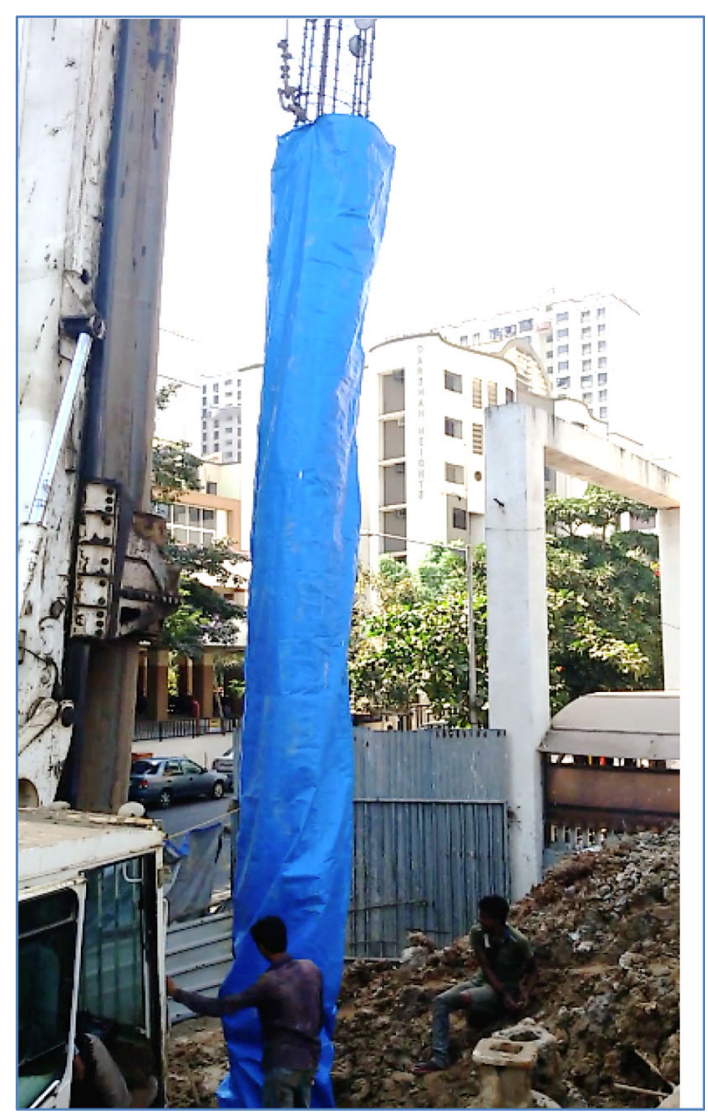

Fig. 8 Geofabric pile liner with LDPE melt coating 


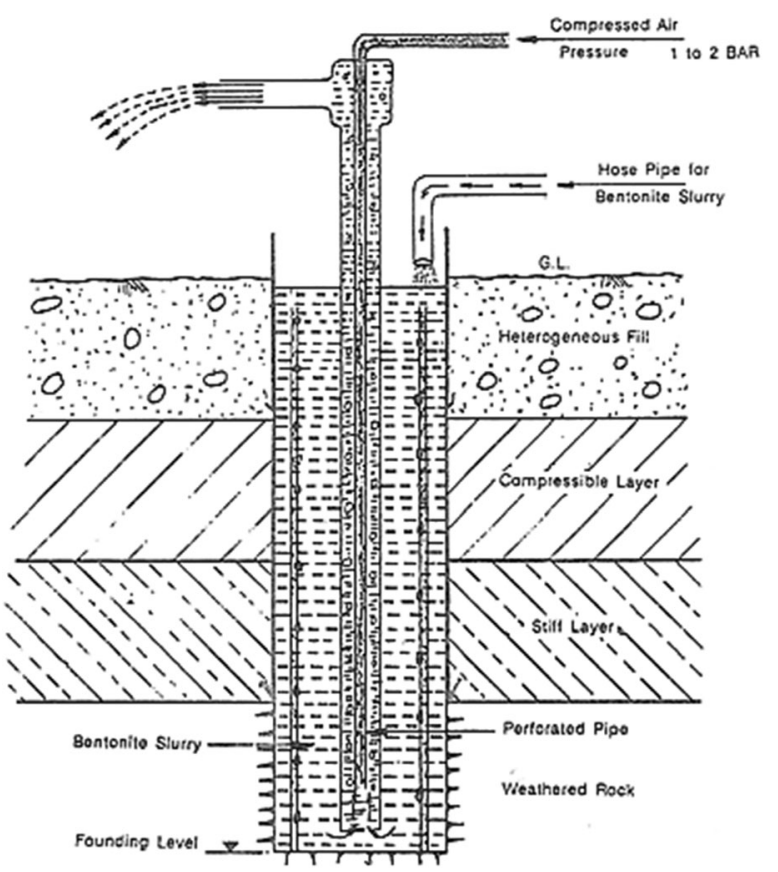

Nates:
1) Perforated pipe of $1.5 \mathrm{~m}$ length $40 \mathrm{~mm}$. dia. shoutd
bo kept $1.5 \mathrm{~m}$ above 1 is lovel
2) tromio pipo of $200 \mathrm{~mm}$. dis, kept about $30 \mathrm{~cm}$. above 2) itemic pipo of $200 \mathrm{~mm}$. dis. kept abou1 $30 \mathrm{~cm}$, above
tip level

Fig. 9 Airlift cleaning arrangement of pile tip

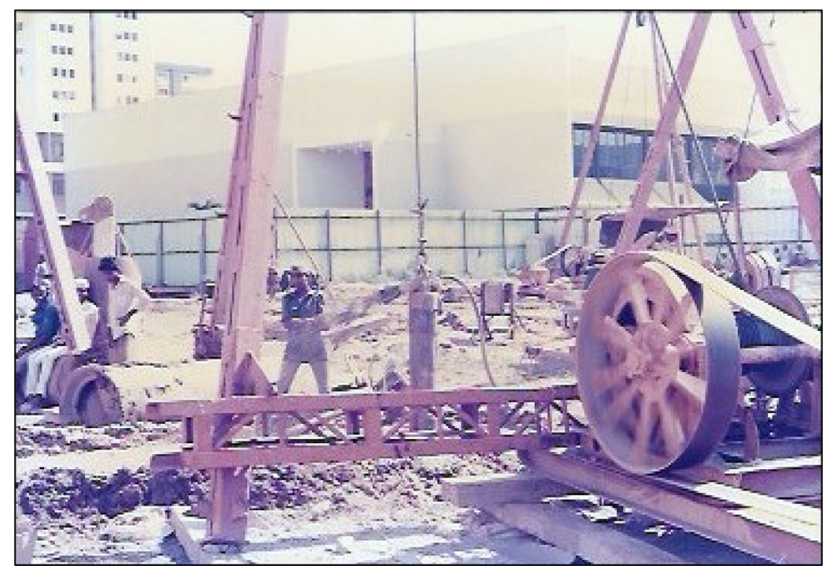

Fig. 10 Airlift cleaning of pile tip

\section{Pile Bore Stability with Polymer Drilling Fluid}

This problem occurs even in rotary piling method, like in Chisel-Bailor method, when a relatively short temporary casing is used. Due to difficulties in casing extraction arising out of limitations of machine capacity, kelly, hoisting length and absence of oscillatory mechanism, the casing depth is limited to 6-8 $\mathrm{m}$, leaving the lower pile shaft vulnerable to necking and pile shaft defects. Bentonite slurry for pile bore stability is avoided due to space constraints and environmental restriction. Use of polymer fluid is a good option but not many piling contractors use it.
Polymer fluid is biodegradable, thus environmental friendly, quantity required is much less than bentonite which partly offsets its high cost and it is more efficient in trapping the bored fine muck and its removal. The slurry can be directly discharged in nearby municipal drains which removes a major hassel in disposing the site slush.

\section{Pile Shaft Integrity with Geofabric Liner}

Permanent pile liners, going up to the start of rock socket, made from woven or non-woven polypropylene can be very effectively used to ensure pile shaft integrity, particularly in bouldery fill or in very soft clays. The liners are wound around the reinforcement cages and the cages are lowered in the pile bores stabilized either by bentonite slurry or by temporary M.S. liners. The alternative of using permanent M.S. liners in such situations becomes costly. Apart from economy, geofabric liners increase the pile concrete durability in aggressive environment. The liners however have to be properly designed to withstand fluid concrete pressure and have toughness to prevent their puncturing in bouldery zone. Figures 6,7 and 8 show typical arrangement for use of fabric liner. With LDPE melt coat on the outer surface of these liners, negative skin friction can be virtually eliminated in soft clays. Geofabric liners have been successfully used in bored piles installed in soft clays in Uran, Nhava Sheva, Navi Mumbai and in bouldery strata of Eksar, Borivali.

\section{Pile Tip Zone Cleaning with Air Lift Method}

This is an issue which really needs to be carefully attended to in piling construction. Due to a small footprint of high rise building, there is a need to adopt high pile capacities, nearly reaching to their structural capacities. The pile construction needs to ensure that in addition to the shaft friction, end bearing is also mobilized to fullest extent to guarantee required capacity without excessive settlement due to a 'soft toe' condition at pile base.

Normally tip zone has to be cleaned twice. First, when pile boring is completed and second, just prior to concreting after the reinforcement cage is lowered and tremie is inserted. While the first cleaning is generally done with a cleaning bucket, the need for the second cleaning is questioned and even dispensed with. This is particularly so when pile boring is done with rotary rigs.

Bentonite or polymer fluid slurry tank and pumping arrangements are absent in rotary piling method and tremie flushing is not carried out prior to concreting. The reinforcement cage scraps the sides of pile bore, when permanent liner is absent, and this deposits the muck at the base of pile. 'Soft Toe' condition with consequent loss of 
Table 1 Suggested pile design parameters based on chisel energy level of founding basalt rock

\begin{tabular}{|c|c|c|c|c|c|c|c|}
\hline $\begin{array}{l}\text { Sr. } \\
\text { no. }\end{array}$ & Rock type & $\begin{array}{l}\text { C.R. } \\
(\%)\end{array}$ & $\begin{array}{l}\text { R.Q.D. } \\
(\%)\end{array}$ & $\begin{array}{l}\text { Minimum, } \mathrm{E}\left(\mathrm{kN} \mathrm{m} / \mathrm{m}^{2} /\right. \\
\mathrm{cm})\end{array}$ & $\begin{array}{l}\text { Socket } \\
\text { length }\end{array}$ & $\begin{array}{l}\text { Safe friction } \mathrm{q}_{\mathrm{f}}(\mathrm{kN} / \\
\left.\mathrm{m}^{2}\right)\end{array}$ & $\begin{array}{l}\text { Safe bearing } \mathrm{q}_{\mathrm{b}}(\mathrm{kN} / \\
\left.\mathrm{m}^{2}\right)\end{array}$ \\
\hline 1 & Tuff, no plastic fines & $>40$ & $0-25$ & 750 & 3 pile dia. & $100-125$ & 3000 \\
\hline 2 & $\begin{array}{l}\text { Tuff with plastic } \\
\text { fines }\end{array}$ & $>40$ & $0-25$ & 750 & 5 pile dia. & $100-125$ & 1800 \\
\hline 3 & Weathered basalt & $>90$ & $>25$ & 2250 & 0.5 pile dia. & $100-150$ & $4000-5000$ \\
\hline 4 & Weathered basalt & $<90$ & $<25$ & 2250 & 3 pile dia. & $100-150$ & $4000-5000$ \\
\hline
\end{tabular}
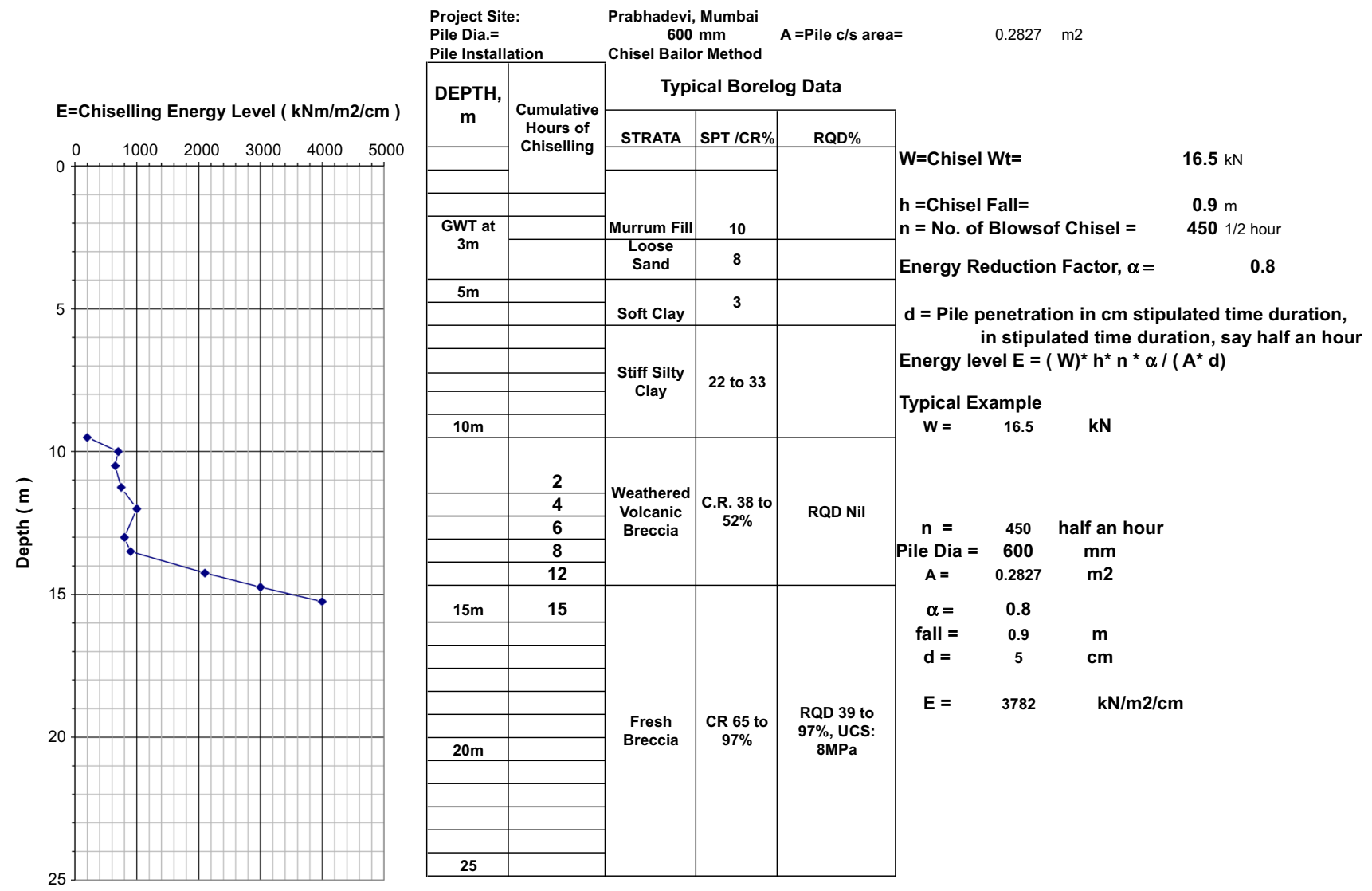

Fig. 11 Chisel penetration data, Prabhadevi, Mumbai site

pile capacity results even when the founding strata is hard Basalt rock.

Compressed airlift flushing method suggested by Datye [1] as illustrated in Fig. 9 is very convenient and should be encouraged. Its use at one of the sites can be seen in Fig. 10.

\section{Pile Termination Criteria}

This is an issue in deep weathered rocks with variable weathering grades. The boreholes show low core recovery and poor RQD. Deciding pile termination criterion is a challenge. The guidelines given below would be useful in ensuring piling quality and optimization in their lengths using one of the two criteria detailed below, viz., Chisel Energy Level and Pile Penetration Ratio. (Both these methods have been incorporated as a quality control tool for Piling in rocks in IRC: 78-2014 [2]).

\section{Chiseling Energy Concept}

In rocks, wherein the socket is formed by chiseling, Datye and Karandikar [3] proposed a simple method based on Chiseling Energy Concept for the pile termination. The 


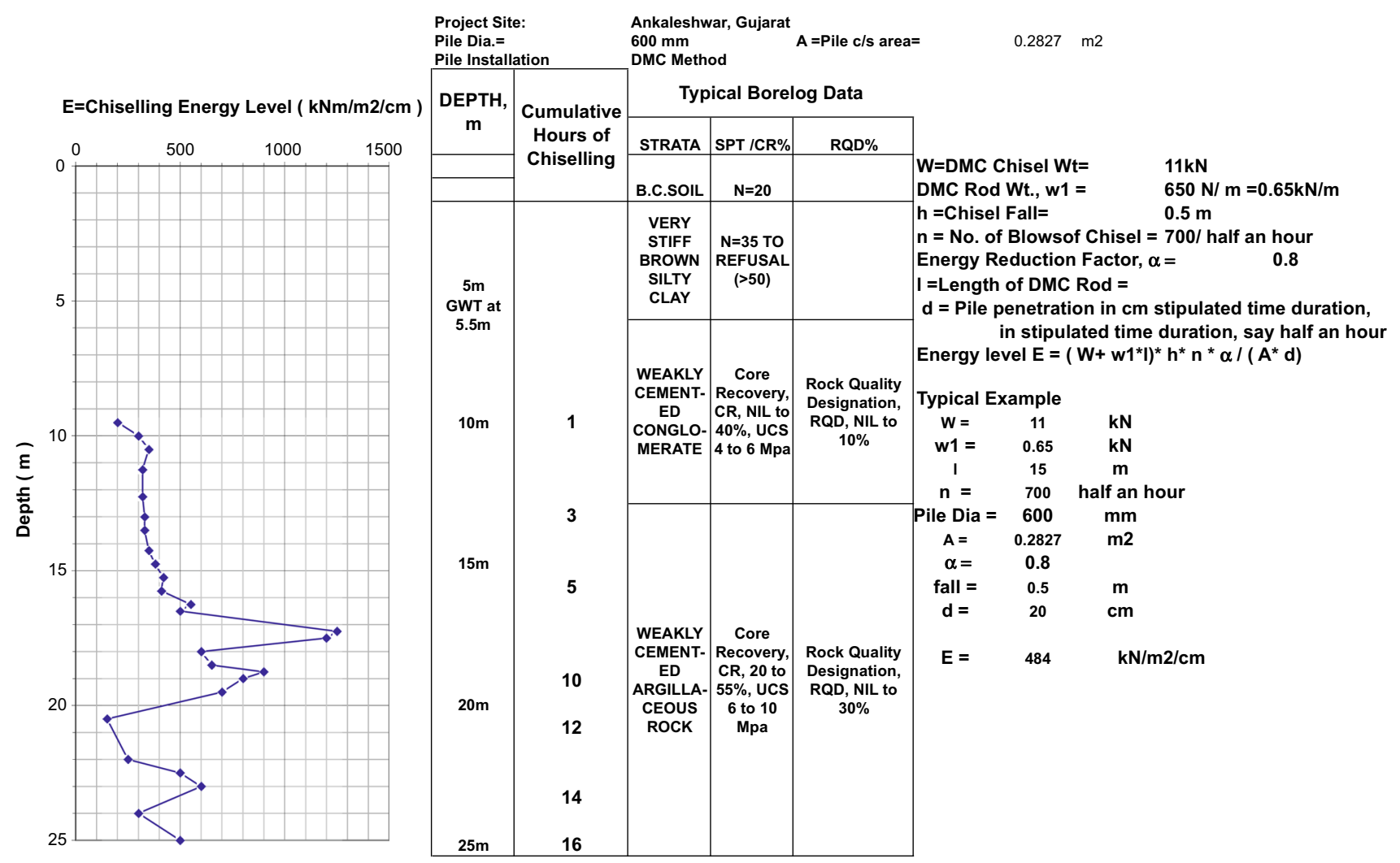

Fig. 12 Chisel penetration data, Ankaleshwar, Gujarat site

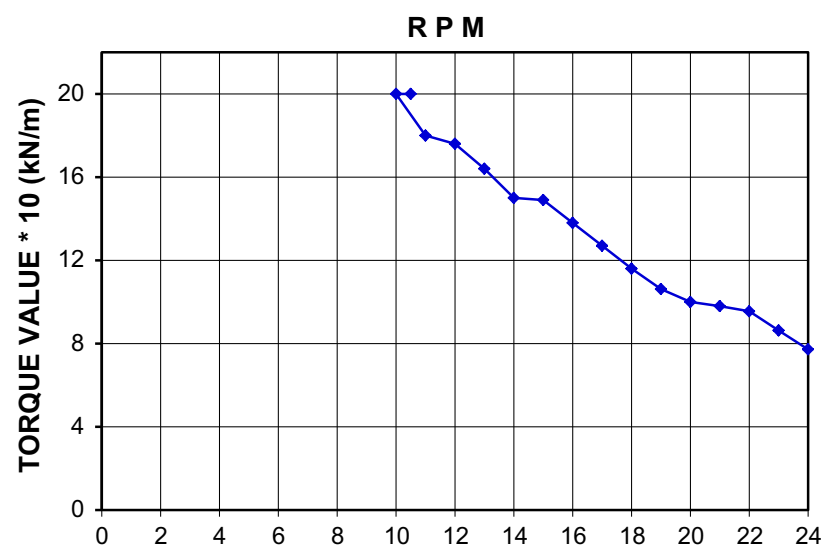

Fig. 13 Typical Torque-RPM diagram of $180 \mathrm{kN}$ m capacity rotary auger rig

response of founding rock strata is expressed in terms of Energy Level, E, (Eq. 1) worked out as under.

$E=\frac{(W \cdot h \cdot n \cdot N)}{(A \cdot d)}$

$\mathrm{E}=$ Chisel energy level in $\mathrm{kN} \mathrm{m} / \mathrm{m}^{2} / \mathrm{cm}, \mathrm{W}=$ weight of Chisel in $\mathrm{kN}$ in Chisel-Bailor method or the weight of Direct Mud Circulation (DMC) chisel along with the DMC rods, in DMC method, $\mathrm{h}=$ fall of chisel in meters given in

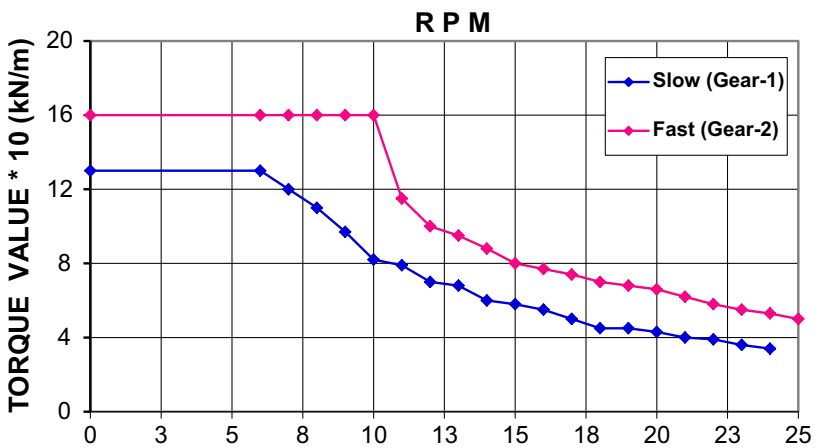

Fig. 14 Typical Torque-RPM Diagram of $130 \mathrm{kN}$ m capacity rotary auger rig

every blow $(\mathrm{m}), \mathrm{n}=$ reduction factor, $0.8-1.0$ based on likely drag on chisel due to slurry, submerged weight of chisel in high ground water, winch rope friction and type of muck (clayey or sandy), based on rock type. $\mathrm{N}=$ no. of blows in the stipulated duration, normally half an hour. $\mathrm{A}=$ nominal pile cross sectional area in $\mathrm{m}^{2}, \mathrm{~d}=$ penetration in $\mathrm{cm}$ into the rock strata in that stipulated duration.

Using analogy of energy imparted in SPT test with corresponding penetration achieved, pile design parameters have been suggested by Datye and Patil [4] as given in Table 1. Capacity estimation based on these parameters is conservative. 
Table 2 Typical PPR rates for rotary auger piling rig, with Torque $180 \mathrm{kN} \mathrm{m}$ and RPM 10 at Versova, Andheri Site. Pile dia. $700 \mathrm{~mm}$

\begin{tabular}{lll}
\hline Rate of penetration $(\mathrm{cm} / \mathrm{min})$ & Type of strata & Pile penetration ratio $(\mathrm{PPR})\left(\mathrm{kN} \mathrm{m} / \mathrm{m}^{2} / \mathrm{cm}\right)$ \\
\hline $40-60$ & Soil & $500-750$ \\
$20-40$ & Highly weathered rock & $750-1500$ \\
$10-20$ & Moderately weathered rock & $1500-3000$ \\
$5-10$ & Slightly weathered breccia & $3000-6000$
\end{tabular}

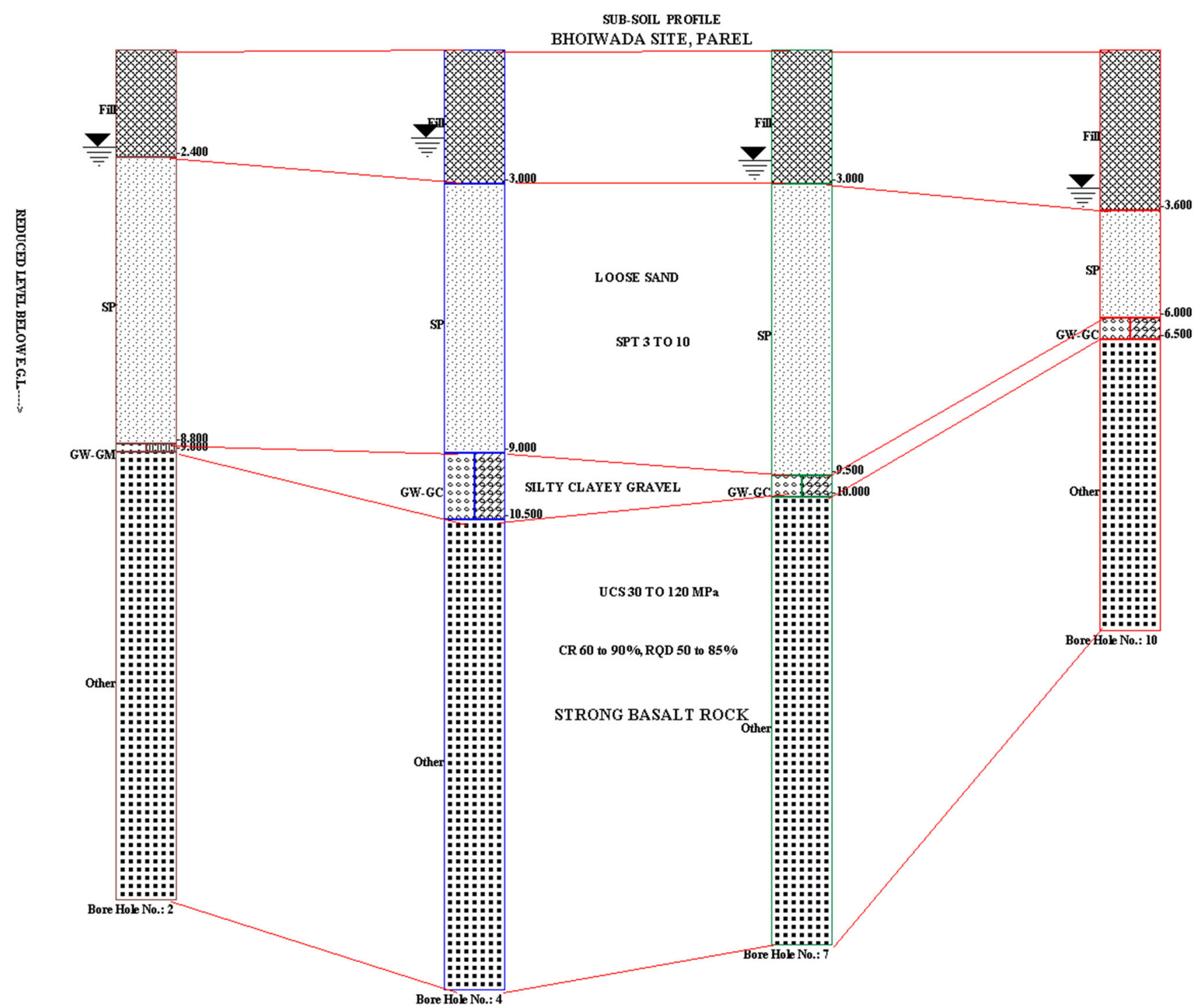

Fig. 15 Subsurface Profile, Bhoiwada, Parel Site, Mumbai

The chisel energy response data can be plotted depth wise side by side with the nearby bore $\log$ and hours of chiseling. The pile termination zone can be decided to further optimize the chiseling effort while also ensuring the pile capacity. Figures 11 and 12 shows such plots for two sites.

\section{Pile Penetration Ratio (PPR) for Rotary Piling}

With use of rotary piling, the energy concept is modified as given in Eq. 2 by Ganpule and Gupte [5].

$P P R=\frac{(2 \cdot \pi \cdot N \cdot T \cdot t)}{(A \cdot d)}$ 
Table 3 PPR (Bhoiwada, Parel Site) values with $180 \mathrm{kN}$ m Torque at RPM 11

\begin{tabular}{llccc}
\hline Depth $(\mathrm{m})$ & Strata & Penetration $(\mathrm{cm} / \mathrm{min})$ & PPR $\left(\mathrm{kN} \mathrm{m} / \mathrm{m}^{2} / \mathrm{cm}\right)$ & Remarks/pile dia. $(\mathrm{mm})$ \\
\hline $0-4.8$ & Loose sandy fill & 32 & 880 & 750 \\
$4.8-6.5$ & Medium silty sand & 8 & 3500 & 750 \\
$6.5-9$ & Weathered rock & 4 & 7000 & 750 \\
Beyond 9 & Slightly weathered basalt & 2 & 14,000 & Remedial piles, 750 mm
\end{tabular}

$T P$ test pile

PPR $=$ Pile Penetration Ratio in $\mathrm{kN} \mathrm{m} / \mathrm{m}^{2} / \mathrm{cm}, \mathrm{N}=\mathrm{RPM}$, $\mathrm{T}=$ Torque in $\mathrm{kN} \mathrm{m}$ corresponding to $\mathrm{RPM}, \mathrm{t}=$ time duration in minutes, normally $10 \mathrm{~min}, \mathrm{~A}=$ pile crosssection area in $\mathrm{m}^{2}, \mathrm{D}=$ pile penetration in $\mathrm{cm}$.

As the resistance to rock cutting increases, RPM decreases and Kelly bar pressure is required to be increased, increasing the Torque. This is reflected in Torque-RPM curve, typically shown in Figs. 13 and 14. Piling manufacturers can furnish Torque-RPM curve specific to the machine used. Some contractors install torque meters on the control panels of hydraulic rigs to measure the torque. Based on borelog and rock quality data, manufacturers can suggest the most suitable rig to be used. It is seen from the Chisel Energy and PPR data of the same site at same depth, that PPR values tends to be 3-5 times larger than chisel Energy values. Both these methods are mainly recommended for deciding pile termination during execution. PPR should not be used to compute pile capacity.

Typical PPR rates observed at Versova, Andheri, Mumbai site are given below in Table 2. (See Fig. 17 for borelog data). PPR are also given for the two Case Study sites in Tables 3 and 4. From Chisel Energy or PPR values it is also possible to assess the time for pile boring and forming required rock socket length.

\section{Case Studies with Large Diameter Bored Piles}

To highlight the challenges and problems in urban environment, all the case studies in this paper are taken for sites in Mumbai.

\section{Case Study 1 (Bhoiwada site)}

At one of the multistoried building sites (Typical borelog in Fig. 15) in Bhoiwada, Parel, Mumbai, following stratification and geotechnical properties were observed. Although bentonite stabilization was initially specified, piling was allowed without its use. Many piles showed poor shaft integrity, revealed in PIT tests and low safe pile capacity as in PDA tests (Refer Table 5). Fallen debris in pile gave 'soft toe' condition. The coring through one of the 'soft toe' piles (Pile No. IP51) actually showed complete absence of concrete in the pile toe.

\section{Stratification and Geotechnical Properties}

The site seemed to be a low lying area and graded with 2.4-4 m thick loose sandy fill. Below the Fill, loose shoreline silty sand deposit of thickness varying from 1.8 to $7.1 \mathrm{~m}$ was present with SPT ' $\mathrm{N}$ ' values ranging from 2 to 7 and having classification, 'SP' or 'SM'. This could be the sand deposited along the shore of the earlier Wadala island, one of the 7 islands of Mumbai. The sandy overburden was lying on a thin layer of completely weathered rock (Virtually soil of GW-GC classification). The Basalt bed rock was moderately strong to very strong with UCS between 30 and $120 \mathrm{MPa}$. Ground water table was within $2-3 \mathrm{~m}$ i.e. in the fill itself.

\section{Remedy}

Many piles were discarded. But building plan allowed only a limited no. of new piles, hence some of the existing piles had to be used with derating. Safe capacity of new pile adopted was $4400 \mathrm{kN}$. This was confirmed by PDA on test piles specifically installed as per new guidelines.

\section{Case Study 2 (Kalbadevi site)}

Similar problems were observed at Kalbadevi site also (Fig. 16), (Refer Tables 6 and 7). The required safe pile capacities for 600 and $750 \mathrm{~mm}$ dia. piles were 1600 and $2800 \mathrm{kN}$ respectively. The dynamic pile load test data, (PDA), however showed that safe capacities were only to the extent of 500-1000 kN (See Table 6). Due to high loads on a smaller foot-print of building, pile layout was congested and it became difficult to plan and install new remedial piles of $4000 \mathrm{kN}$ safe vertical capacity, in the spaces between the defective piles. All new piles were installed with M.S. liners and pile tip zones were meticulously cleaned by polymer fluid. 
SUB-SOIL PROFILE

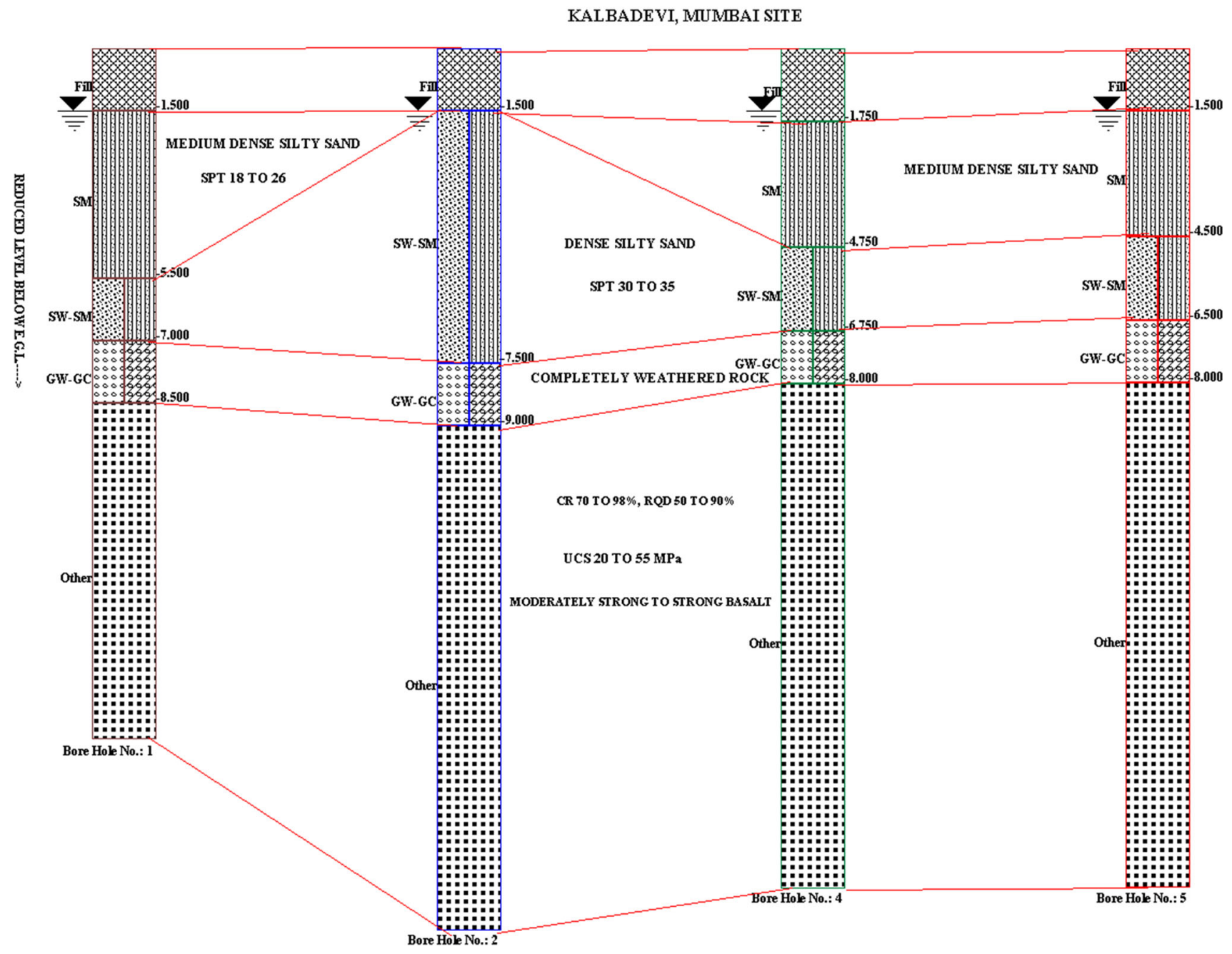

Fig. 16 Subsurface profile Kalbadevi site, Mumbai

Table 4 PPR (Kalbadevi Site) values with $180 \mathrm{kN} \mathrm{m}$ Torque at RPM 11

\begin{tabular}{lllll}
\hline Depth $(\mathrm{m})$ & Strata & Penetration $(\mathrm{cm} / \mathrm{min})$ & PPR $\left(\mathrm{kN} \mathrm{m} / \mathrm{m}^{2} / \mathrm{cm}\right)$ & Remarks/pile dia. $(\mathrm{mm})$ \\
\hline $0-1.5$ & Murrum fill & $10-20$ & $1250-2450$ & 800 \\
$1.5-7$ & Silty sand & $5-10$ & $2450-5000$ & 800 \\
$7-8$ & Weathered basalt & $3-5$ & $5000-8000$ & 800 \\
Beyond 8 & Slightly weathered basalt & 1 & 25,000 & 800 \\
\hline
\end{tabular}

\section{Case Study 3 (Versova site)}

At yet another site of multistoried buildings at Versova near seashore, soft marine clay was present below loose sandy strata overlying weathered breccia. (Borelog in Fig. 17). M.S. Liners taken up to weathered rock were provided to all piles.

\section{Case Study with Micro-piles/Small Diameter Bored Piles}

\section{General}

Great caution needs to be exercised in use of micro-piles for supporting building loads. There is risky trend of taking 


\section{MAHIM SITE}

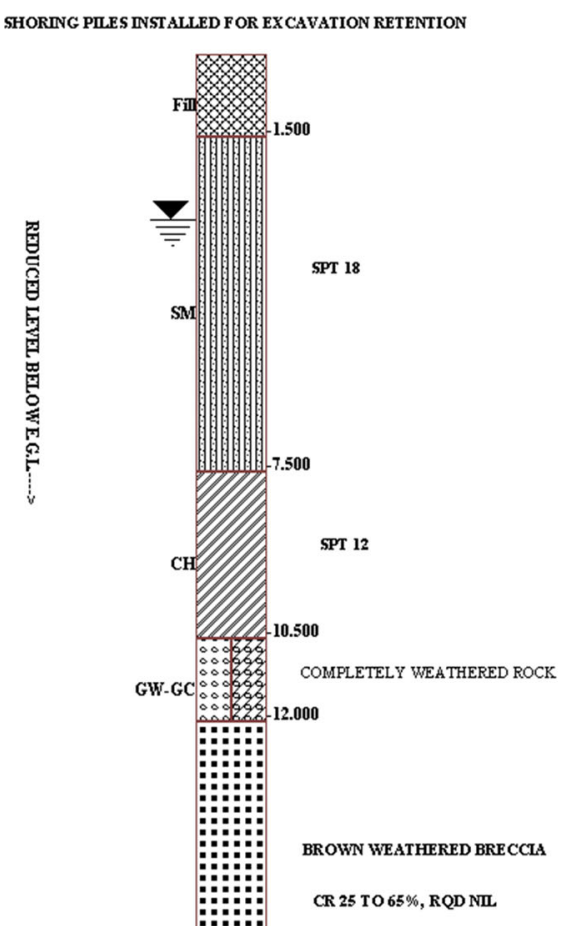

CR 32 TO $70 \%$, RQD 10 TO $50 \%$
SUB-SOIL PROFILE

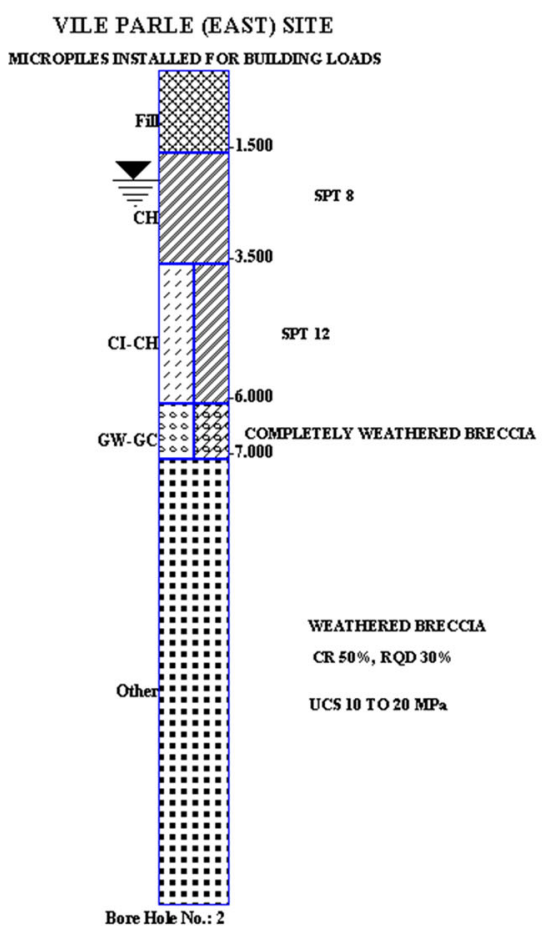

VERSOVA, ANDHERI SITE

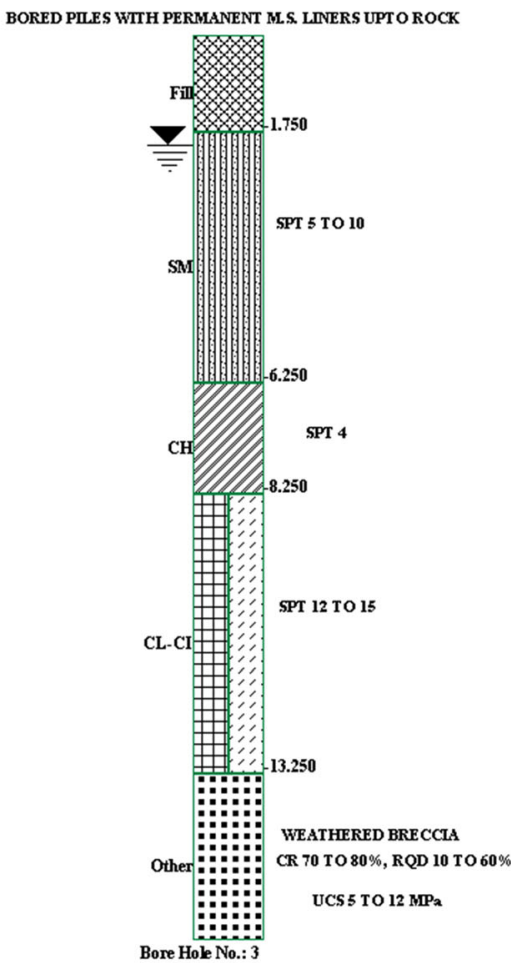

Fig. 17 Borehole data Mahim, Vile Parle and Versova sites, Mumbai

high capacities for micro-piles. But it must be kept in mind that, (a) lateral capacity of micro-pile is very small. (b) Micro pile, the way it is constructed commonly in Mumbai, is actually a small dia bored cast-in-situ pile, vulnerable to all deficiencies of bored-cast-in-situ piles mentioned earlier. (c) The load is essentially mobilised due to shaft friction and FOS of 2.5 is not always ensured. (d) Pile settlement may exceed failure settlement of (pile dia/10), under loads less than 2.5 times safe load. (e) There is PVC or M.S. liner in the overburden but no liner in the rock socket zone and hence the main pile segment contributing to capacity is vulnerable to corrosion, necking, 'soft toe' etc. Following case study will illustrate these aspects.

\section{Case Study 4 (Vile Parle site)}

At a site in Vile Parle, micro-piles were installed for supporting building extension. Subsurface stratification was as follows:

Layer 1: Backfilled Soil: $1.5 \mathrm{~m}$ thick

Layer 2: Grey Stiff Clay: $1.8 \mathrm{~m}$ thick, $\mathrm{N} 8, \mathrm{CH}$

Layer 3: Yellow Stiff Clay with Gravel: $2.5 \mathrm{~m}, \mathrm{~N} 12, \mathrm{CH}$

Layer 4: Completely Weathered Rock: 0.5-1 m, N 50, SM-SC

Layer 5: Moderately Weathered Volcanic Breccia: Beyond $7 \mathrm{~m}$ with CR 50\%, RQD 30\%, UCS 10-20 MPa

$300 \mathrm{~mm}$ dia. micro-pile, $8.5 \mathrm{~m}$ long with $2 \mathrm{~m}$ socket in rock was designed for a safe capacity of $400 \mathrm{kN}$. The load test indicated that settlement for $400 \mathrm{kN}$ was just $1.2 \mathrm{~mm}$ 
Table 5 Mumbai Bhoiwada Site. pile dynamic analyser (PDA) load test data. Piles installed with HR 180 rotary rig with 2 Pile dia. Socket in rock. All piles $750 \mathrm{~mm}$ dia

\begin{tabular}{|c|c|c|c|c|c|c|c|c|}
\hline Bldg. & Pile no. & PIT comments & $\mathrm{Q}_{\mathrm{f}}(\mathrm{kN})$ & $\mathrm{Q}_{\mathrm{b}}(\mathrm{kN})$ & Total capacity $(\mathrm{kN})$ & Set $(\mathrm{mm})$ & Total settlement $(\mathrm{mm})$ & Remarks \\
\hline $1-\mathrm{A}$ & 1P 63 & No PIT & & & 1240 & 5 & $13.3 / 3$ blows & Test ok \\
\hline $2-\mathrm{A}$ & 1P52 & Bulb@4m & & & 520 & 8 & $14.3 / 2$ blows & Test ok \\
\hline $3-A$ & 1P60 & Pile short & & & 990 & 14 & 14.1/6 blows & Pile cored \\
\hline $4-\mathrm{A}$ & 1P53 & Pile built up & 760 & 490 & 1250 & 8 & $27.8 / 5$ blows & 1st blow \\
\hline $4-\mathrm{A}$ & 1P53 & & 1400 & 1070 & 2470 & 7 & $30.5 / 5$ blows & 3rd blow \\
\hline $5-\mathrm{B}$ & $2 \mathrm{P} 153$ & No PIT & & & 1880 & 10 & 19.0/7 blows & Test ok \\
\hline $6 \mathrm{~B}$ & $2 \mathrm{P} 40$ & Ok & & & 4560 & 1 & 11.1/5 blows & Test ok \\
\hline 7-C & 3P136 & $\mathrm{Ok}$ & & & 8070 & 1 & $7.2 / 3$ blows & Test ok \\
\hline $8-A$ & 1P-20 & No PIT & & & 1530 & 12 & 26.7/9 blows & Test ok \\
\hline $8-A$ & IP-20 & & & & 2980 & 10 & $32.6 / 9$ blows & \\
\hline 9 & TP1 & Bulb@3m & & & 13,000 & 0.1 & $8.5 / 3$ blows & Ok \\
\hline $10-\mathrm{A}$ & 1P52 & Bulb@4m & & & - & - & - & Major crushing \\
\hline 11 & $\mathrm{TP} 2$ & Ok & & & - & - & - & - \\
\hline 12 & TP3 & $\mathrm{Ok}$ & 7240 & 3720 & 10,960 & 0.1 & 10.7 & Test ok \\
\hline
\end{tabular}

Table 6 Mumbai Kalbadevi site. Pile dynamic analyzer (PDA) load test data. Piles installed with HR180 rotary rig with 2 pile dia. socket in rock, all piles $800 \mathrm{~mm}$ dia

\begin{tabular}{|c|c|c|c|c|c|c|c|c|c|c|}
\hline Pile no. & Length $(\mathrm{m})$ & $\mathrm{Q}_{\mathrm{f}}(\mathrm{kN})$ & $\mathrm{Q}_{\mathrm{b}}(\mathrm{kN})$ & $\mathrm{Q}_{\mathrm{t}}(\mathrm{kN})$ & Sett. at $\mathrm{Q}_{\mathrm{t}}(\mathrm{mm})$ & $\mathrm{q}_{\mathrm{f}}\left(\mathrm{kN} / \mathrm{m}^{2}\right)$ & $\mathrm{q}_{\mathrm{b}}\left(\mathrm{kN} / \mathrm{m}^{2}\right)$ & $\mathrm{Q}_{\mathrm{t}}\left(\mathrm{kN} / \mathrm{m}^{2}\right)$ & $\mathrm{Q}_{\mathrm{safe}}(\mathrm{kN})$ & PIT defect \\
\hline 58 & 6.23 & & & & & & & & & At $3.4 \mathrm{~m}$ \\
\hline 58 & 5.2 & 690 & 910 & 1600 & 12.1 & 103 & 1800 & 3183 & 1000 & At $3 \mathrm{~m}$ \\
\hline 40 & 5.74 & & & & & & & & & At $3.3 \mathrm{~m}$ \\
\hline 64 & 6.0 & & & & & & & & & At $3.9 \mathrm{~m}$ \\
\hline 121 & 7.6 & & & & & & & & & At $6 \mathrm{~m}$ \\
\hline 121 & 8.0 & 1020 & 290 & 1310 & 12 & 155 & 578 & 2606 & & At $6.9 \mathrm{~m}$ \\
\hline 99 & 5.95 & & & & & & & & & Soft toe \\
\hline 102 & 6.45 & & & & & & & & & Soft toe \\
\hline 73 & 5.8 & 1460 & 1340 & 2800 & 108 & 222 & 2660 & 7060 & 2250 & \\
\hline
\end{tabular}

Table 7 Remedial pile details—Kalbadevi site

\begin{tabular}{|c|c|c|c|c|c|c|}
\hline Type & $\mathrm{Q}_{\text {safe-vert. }}(\mathrm{kN})$ & Qallow $_{\text {horizontal }(\mathrm{kN})}$ & $\mathrm{Q}_{\text {uplift }}(\mathrm{kN})$ & Allowable settlement $(\mathrm{mm})$ & Concrete grade & Remarks \\
\hline $\mathrm{I}-\mathrm{A}$ & & 70 & & & M35 & Existing, used for only hor. loads \\
\hline I-B & & 110 & & & M35 & \\
\hline II-A & 1250 & 70 & & 12 & M35 & Existing \\
\hline II-B & 1600 & 110 & & 12 & M35 & Existing \\
\hline III-A & 2500 & 70 & & 8 & M35 & Existing \\
\hline III-B & 3100 & 110 & 150 & 8 & M35 & Existing \\
\hline IV & 4000 & 110 & 150 & 6 & M40 & New pile \\
\hline $\mathrm{V}$ & 4000 & 110 & 900 & 6 & M40 & New pile \\
\hline
\end{tabular}

but for $800 \mathrm{kN}$ it increased to $15 \mathrm{~mm}$ and at $850 \mathrm{kN}$ it failed with settlement reaching $33 \mathrm{~mm}$. Factor of safety of 2.5 was not met. Typical load settlement curve of micropile test is enclosed (Fig. 18). Allowing very high loads on micro-piles is definitely risky.

\section{Micro-piles: Guidelines}

(a) For design of micro-piles, IRC:SP:109-2015 [6] should be followed. 
Fig. 18 Typical micro-pile load test data. $300 \mathrm{~mm}$ dia, $40 \mathrm{~T}$ design capacity, $8.5 \mathrm{~m}$ long with $2 \mathrm{~m}$ socket in rock
MICRO PILE LOAD TEST AT VILE PARLE, MICROPILES SUPPORTING BUILDING EXTENSION

\begin{tabular}{|c|c|c|c|}
\hline $\begin{array}{c}\text { Load } \\
\text { (T) }\end{array}$ & Sett., mm & Load, T & Sett., mm \\
\hline 0 & 0.000 & 77.715 & 12.543 \\
\hline 7.065 & 0.080 & 84.780 & 21.98 \\
\hline 14.130 & 0.217 & 84.780 & 33.10 \\
\hline 21.195 & 0.380 & 70.650 & 34.05 \\
\hline 28.260 & 0.660 & 56.520 & 34.06 \\
\hline 35.325 & 0.937 & 42.390 & 33.96 \\
\hline 42.390 & 1.237 & 28.260 & 33.66 \\
\hline 49.455 & 1.837 & 14.130 & 33.28 \\
\hline 56.520 & 3.773 & 0.000 & 30.723 \\
\hline 63.585 & 5.093 & & \\
\hline 70.650 & 6.963 & & \\
\hline
\end{tabular}

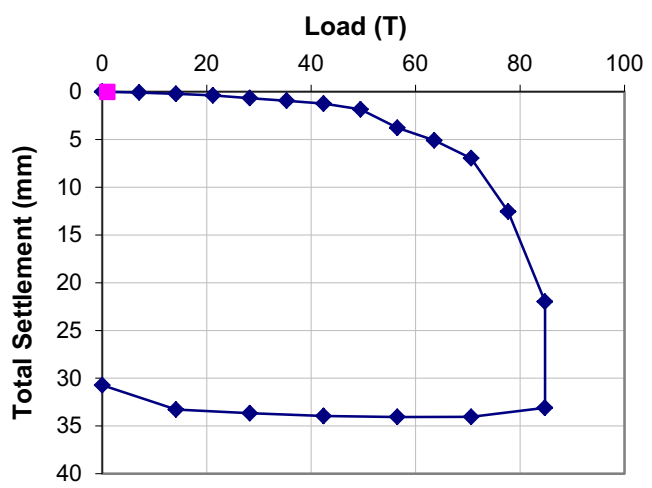

(b) Micro-piles if used for shoring, then they should be provided with M.S. liners rather than PVC lines and laterally restrained by props or anchors.

(c) The gaps between the shoring micro-piles should be filled up with PCC/M.S. plates to prevent seepage of water or soil erosion from adjoining plot into the basement pit.

(d) The foundation details of adjoining buildings should be studied. For this purpose, trial pits may be taken near the external columns.

(e) Anchors should be avoided if adjoining building is on piles.

(f) Ground subsidence in adjoining plot should to be made good.

\section{Bored Piles Used as Shoring Piles for Deep Excavations}

Quality control challenges brought out earlier exist even for bored cast-in-situ piles used for shoring deep excavations. Karandikar [7] has brought out the relevant aspects of shoring pile design generally as per CIRIA 104 and same may be referred. Only guidelines are enumerated below to focus on related quality control issues. Photographs, 19, 20, 21 and 22 are enclosed to highlight nondefective and defective shore piling work at Mahim, Mumbai site. Borehole at Mahim site is shown in Fig. 17.

\section{Difficulties in basement construction}

The basements are free of floor space index (FSI) and mandatory parking requirements are large, which means the developers have to go in for 2 or 3 level basement parking. The basement plan extends right up to $1.5 \mathrm{~m}$ from the plot boundary, leaving very little space for constructing rubble masonry gravity retaining wall. Shoring piles become necessary, internal propping comes in the way of

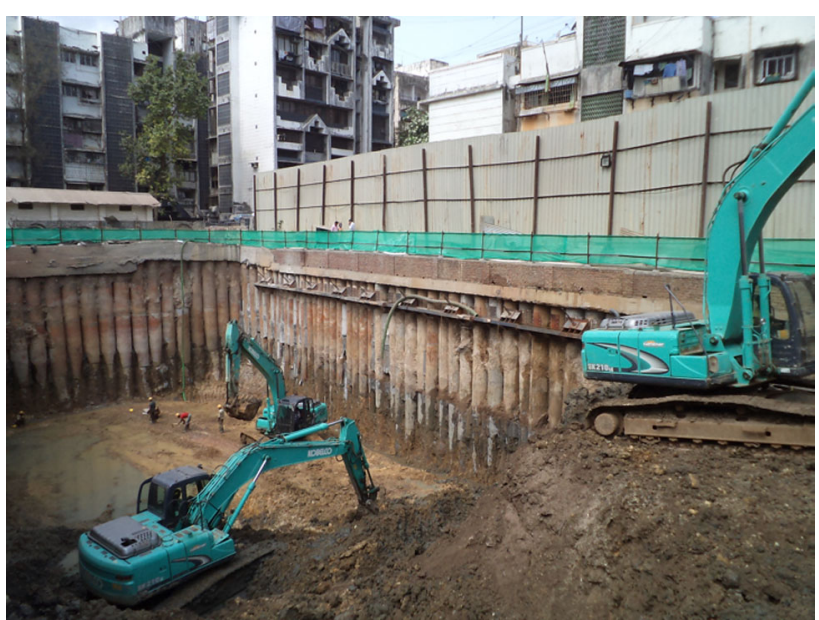

Fig. 19 Properly designed shoring piles with anchors

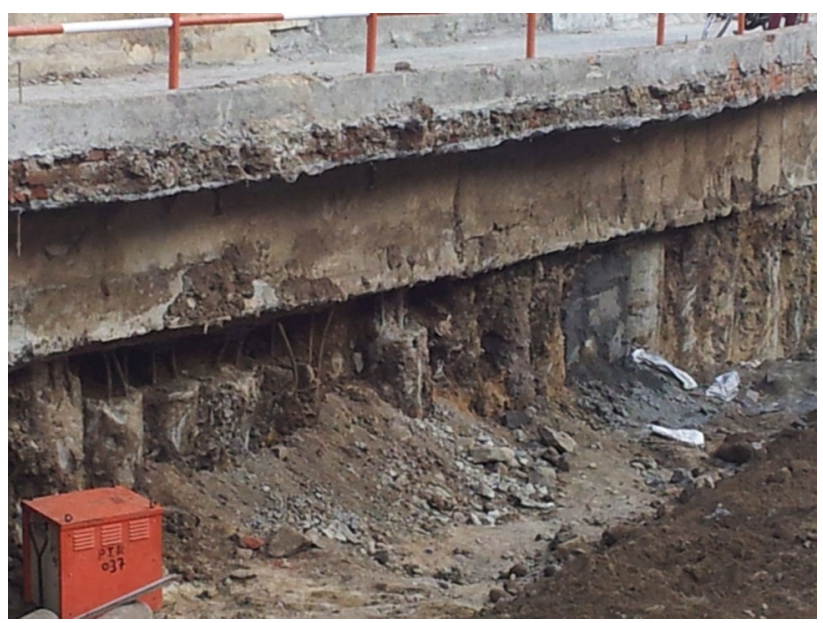

Fig. 20 Defect in shoring piles near tie beam

working space and is avoided and hence restraining anchors are required. They would penetrate in adjoining plot. If the building in adjoining plot is on footings, then anchors have to penetrate much below the stressed zone of 


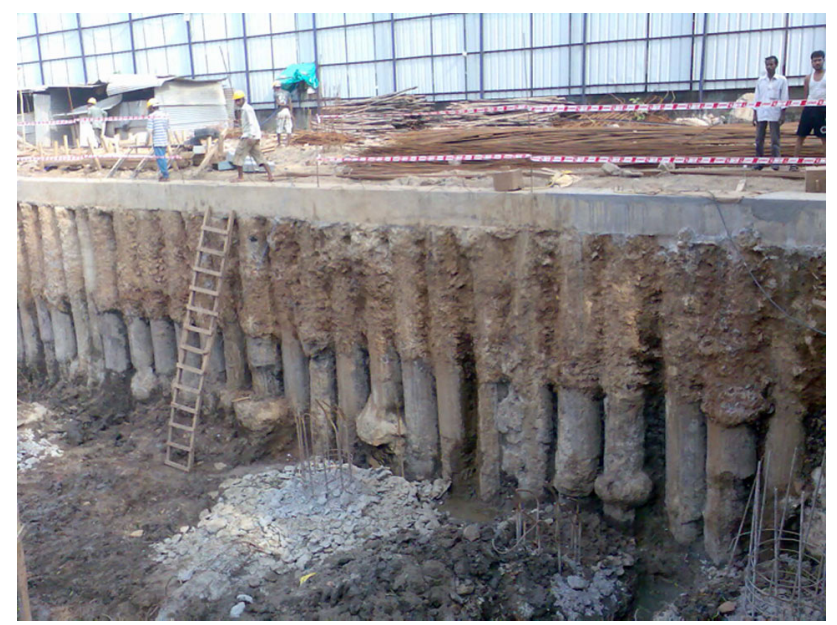

Fig. 21 Defects at tips of shoring piles

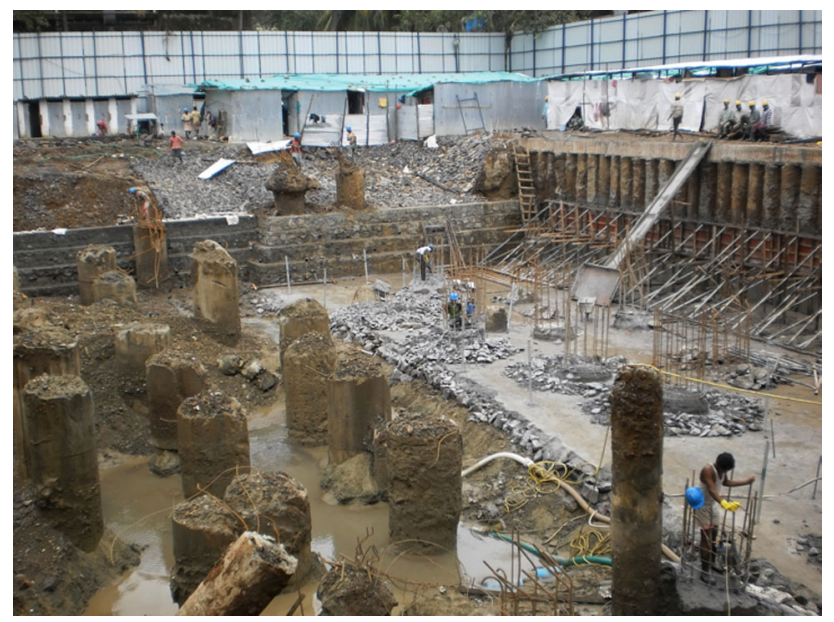

Fig. 22 Rubble wall and shoring piles without anchors for single basement in Andheri site

footings. The scheme has to be discussed with neighbours for their concurrence and for ensuring safety of their building. If adjoining building is on piles, then anchors have to be avoided. Large diameter piles can then be installed without anchors on 'stand alone' design. To avoid the anchors, diaphragm wall and 'Top Down Construction' may also be planned with supports given by basement floor slabs (Figs. 19, 20, 21, 22).

\section{Design Issues Often Overlooked}

(a) Surcharge should be considered at G.L. due to material stacking/movement of construction machinery. (b) Initial level of GWT and its subsequent lowering in stage wise excavation should be considered. (c) Anchors penetrating in adjoining plot or road should be de-stressed after basement construction. (d) Free length of anchor should have
M.S. Sheaths (not PVC), and pass 4 times footing widths below the footings in adjoining plot. (e) Shoring piles should go below basement excavation level unless benches are provided at higher level to give lateral restraint.

\section{Summary Guidelines for Bored Piling}

In the light of the quality control issues of bored piles installed in growing urban environment as highlighted in this paper, some summary guidelines are given below:

- Select an appropriate auger piling rig considering local geology, rock strength, its in-situ condition and site access.

- Ensure pile bore stability using polymer drilling fluid.

- Clean the pile tip zone by airlift method.

- Provide geofabric pile liner to ensure pile shaft integrity.

- In the test pile or the first few piles, compute PPR (or chisel energy parameter if DMC or chisel bailor method is used), as the pile boring proceeds and decide the minimum pile termination PPR.

- Store rock samples marking their depths and PPR.

- Check whether the required pile socket length is obtained or not.

- Geotechnical investigation report should be available at site showing borehole layout and core-boxes with soil and rock samples for comparison with bored/augered soil and rock material.

- Ground level at the time investigation and the actual grade level at the time of piling should be clearly marked at site for correlation of pile founding level and borehole data.

- Consultant's drawing showing pile layout, their capacities and stipulated socket lengths should be available at site office.

- Carry out PIT for all piles and PDA for a select piles to confirm the pile shaft integrity and pile capacities.

\section{Conclusions}

High-rise buildings are becoming more common. The plot footprints in urban areas are relatively small which demand larger safe pile capacities, nearly approaching their structural capacities. Defective piling just cannot be tolerated. The need for closer quality control on piling therefore becomes an absolute necessity. The challenges to quality control in piling have been discussed in this paper and guidelines are given for adequately meeting those challenges. 
Acknowledgements The author wishes to thank the Editorial Board of Indian Geotechnical Journal for giving him the opportunity of sharing his experience in high lighting the challenges to quality control in bored piling in growing urban environment. He is thankful to many structural consultants, Shirish Patel Associates Consultants, Dr Kelkar Designs, Pravin Gala Consultants, Patel Kulkarni Consultants, just to name a few, for involving him in their prestigious projects. Discussions with geotechnical consultants, Mr. Shekhar Vaishampayan, and Mr. Suhas Golam and Mr. Kedar Birid have been very useful and thanks are extended to them.

\section{References}

1. Datye KR (1990) Bored piling in Bombay region. In: Proceedings of Indian geotechnical conference, IGC-90. 20-22 Dec 1990, Mumbai, India

2. IRC:78-2014 Standard specifications and code of practice for road bridges, section: VII, foundations and substructure. Indian Roads Congress
3. Datye KR, Karandikar DV (1988) Bored piling in Bombay region. In: Proceedings of the 1st international geotechnical seminar on deep foundations on bored and auger piles. 7-10 June 1988, Ghent, Belgium

4. Datye KR, Patil JR (1993) Bored cast in situ piles in weathered rocks-evaluation of design parameters. In: Proceedings of the 2 nd international geotechnical seminar on deep foundations on bored and auger piles. 1993, Ghent, Belgium

5. Ganpule VT, Gupte SM (2004) Study of theoretical and observed capacities of bored cast-in situ piles in tuff, breccia and weathered basalt. In: Proceedings of 5th international conference on case histories in geotechnical engineering. 13-17 Apr 2004, New York, USA

6. IRC:SP:109-2015 Guidelines for design and construction of small diameter piles for road bridges. Indian Roads Congress

7. Karandikar DV (2013) Earth retaining schemes for basements and deep excavations, Keynote lecture. In: Proceedings of DFI-IGSIITB-APS conference. Nov 2013, Mumbai, India 